Jurnal Penyuluhan, Maret 2016 Vol. 12 No. 1

\title{
Partisipasi Petani dalam Replanting Kelapa Sawit di Provinsi Jambi
}

\section{Participation of Farmers in the Replanting of Palm Oil in the Jambi Province}

\author{
Shinta Anggreany ${ }^{1}$, Pudji Muljono ${ }^{2}$, Dwi Sadono ${ }^{2}$ \\ ${ }^{1}$ Program Studi Pascasarjana Ilmu Penyuluhan Pembangunan, Fakultas Ekologi Manusia, Institut Pertanian Bogor, Bogor \\ ${ }^{2}$ Departemen Sains Komunikasi dan Pengembangan Masyarakat, Fakultas Ekologi Manusia, \\ Institut Pertanian Bogor, Bogor
}

\begin{abstract}
This study aims to: 1) analyze the participation level of farmer in the oil palm replanting; 2) analyze the relationship between internal and external characteristics of farmers innovation perception of oil palm replanting; and 3) analyze the relationship between innovation perception replanting and farmer participation in the oil palm replanting. This research was conducted at Sungai Bahar sub district, Muaro Jambi district with survey method. The total sample of this research is 83 people. The analytical method used are descriptive qualitative and correlation analysis. The conclusion of this study: 1) The level of farmer participation on oil palm replanting was categorized as low due to economic factors and lack of extension; 2) farmer internal and external characteristics, that connected with farmer innovation perception of replanting oil palm were conduction level, extension frequency, and amount of plantation impact of and; 3) Innovation perception level of oil palm replanting was not conneted with farmer participation level in replanting of oil palm except in the aspect of triability level.
\end{abstract}

Keywords: participation, replanting, oil palm

\begin{abstract}
Abstrak
Penelitian ini bertujuan untuk: 1) menganalisis tingkat persepsi terhadap inovasi dan tingkat partisipasi petani dalam replanting kelapa sawit; 2) menganalisis hubungan antara karakteristik internal dan eksternal dengan persepsi terhadap inovasi replanting petani kelapa sawit; dan 3) menganalisis hubungan persepsi terhadap inovasi replanting dengan partisipasi petani dalam replanting kelapa sawit. Penelitian ini menggunakan metode survei dan dilaksanakan di Kecamatan Sungai Bahar, Kabupaten Muaro Jambi. Jumlah sampel penelitian ini adalah 83 orang. Metode analisis yang digunakan adalah deskriptif dan korelasi. Kesimpulan penelitian ini adalah 1) Tingkat partisipasi petani dalam replanting kelapa sawit termasuk kategori rendah dikarenakan faktor ekonomi dan kurangnya penyuluhan yang diberikan; 2) karakteristik internal dan eksternal petani yang berhubungan dengan persepsi terhadap inovasi replanting petani dalam replanting kelapa sawit adalah tingkat pendidikan, frekuensi penyuluhan, dan dampak perkebunan besar yang dirasakan petani; dan 3) persepsi terhadap inovasi replanting kelapa sawit tidak berhubungan dengan partisipasi petani dalam replanting kecuali pada aspek tingkat triabilitas.
\end{abstract}

Kata kunci: partisipasi, replanting, kelapa sawit

\section{Pendahuluan}

Upaya percepatan pengembangan perkebunan rakyat dalam program revitalisasi sektor perkebunan yang dilakukan melalui perluasan, peremajaan dan rehabilitasi tanaman perkebunan dan memiliki tujuan untuk meningkatkan daya saing pada komoditas sektor perkebunan dengan meningkatkan produktivitas serta mengembangkan industri hilir, sehingga mendukung perkembangan wilayah dan meningkatkan pendapatan masyarakat. Revitalisasi perkebunan juga didukung oleh berbagai peraturan pemerintah diantaranya adalah. Peraturan Menteri Pertanian (PMP) Nomor: 33/Permentan/OT.140/7/2006 tentang Pengembangan Perkebunan melalui Program Revitalisasi Perkebunan. Luas perkebunan rakyat pada komoditas kelapa

\footnotetext{
${ }^{1}$ Korespondensi penulis

E-mail: Shintaanggreany@gmail.com
}

sawit tahun 2010 mencapai $3.314663 \mathrm{Ha}$, meningkat dari tahun sebelumnya yaitu mencapai $3.013 .973 \mathrm{Ha}$ (Dirjen Perkebunan, 2013). Luas wilayah perkebunan kelapa sawit di Provinsi Jambi menurut data BPS tahun 2012 mencapai 532.293 Ha dengan tanaman belum menghasilkan mencapai $110.259 \mathrm{Ha}$, tanaman menghasikan 417.304 Ha dan jumlah tanaman tua mencapai 4.730 Ha. Seiring dengan peningkatan perkembangan kelapa sawit, banyak tanaman kelapa sawit yang telah berumur di atas 25 tahun yang ditandai dengan penurunan produktivitas menjadi sebesar 12 ton/Ha/tahun sehingga perlu untk dilakukan replanting (peremajaan) agar bisa berproduksi secara normal kembali.

Mengingat usia kelapa sawit yang sudah memasuki masa tidak produktif maka replanting 
kelapa sawit perlu segera dilakukan oleh petani di Kecamatan Sungai Bahar saat ini seharusnya telah terlaksana secara keseluruhan, namun hanya sebagian kecil petani yang sudah melakukannya. Hal ini dapat disebabkan oleh adanya perbedaan persepsi petani terhadap sesuatu, sehingga dapat memengaruhi partisipasinya. Permasalahan lainnya yang dihadapi petani saat ini adalah replanting merupakan suatu inovasi yang baru bagi petani, ketakutan petani kehilangan mata pencahariannya apabila tanaman kelapa sawitnya di-replanting dan keterbatasan modal yang dimiliki.

Pada awal tahun 2011 sebelum dilakukannya demplotpercontohan olehDinas PerkebunanProvinsi Jambi berkerja sama dengan BUMN, beberapa orang petani telah melakukan replanting pada kebun sawitnya secara mandiri dan menggunakan teknik tebang pilih/tebang sisip dengan inisiatif dan modal sendiri. Hingga saat ini semakin banyak petani yang mulai melakukan peremajaan dengan sistem tersebut, namun masih ada petani yang belum melakukan replanting hingga saat ini. Sistem yang digunakan dalam demplot percontohan adalah sistem replanting konvensional tumpang sari yang diperkenalkan pada tahun 2011 yaitu salah satu sistem replanting dengan menumbang habis tanaman yang tua, menggantinya dengan tanaman baru serta menanam tanaman pangan dan palawija di antara tanaman baru untuk menambah pendapatan petani

Menurut Herawati dan Pulungan (2006), partisipasi yang terus tumbuh dan juga berkembang menjadi hal yang sangat penting dalam sebuah kegiatan pembangunan. Sebuah proses pembangunan sangat terkait dengan partisipasi masyarakat dalam, pembangunan tersebut dapat dipengaruhi pola fikir dan juga persepsinya dalam pembangunan tersebut. Dipokusumo (1999) dan Purwati (2001) dalam Suparti (2004) menjelaskan bahwa persepsi dan juga partisipasi merupakan suatu konsep yang saling berkaitan satu sama lain,dan pada umumnya sebelum orang berpartisipasi dalam suatu kegiatan maka akan didahului oleh persepsi dan sikapnnya terhadap suatu objek tersebut dan kemudian barulah muncul partisipasi. Sejalan dengan hasil penelitian Khakheili dan Zamani (2009) yang menyatakan bahwa persepsi petani memiliki efek yang cukup signifikan terhadap partisipasi petani dalam pengelolaan irigasi di Negara Iran. Hasil penelitian tersebut menunjukkan bahwa terdapat keterkaitan yang sangat kuat antara persepsi 2 dan partisipasi, sama halnya kegiatan pembangunan dalam hal ini replanting kelapa sawit, maka diperlukan persepsi serta partisipasi petani yang baik hingga dapat mendukung kegiatan tersebut. Sementara itu hasil penelitian Neupane (2002) dan Zbinden dan Lee (2005) menyatakan bahwa faktor internal seperti umur, kepemilikan lahan, jumlah anggota keluarga, pendapatan, dan persepsi masyarakat sebagai faktor yang juga sangat memengaruhi partisipasi masyarakat dalam kegiatan pengelolaan hutan di Nepal dan Kostarika. Dalam penelitian ini terdapat faktor internal dan eksternal yang diamati untuk melihat partisipasi petani dalam replanting kelapa sawit di Provinsi Jambi.

Tujuan penelitian ini adalah (1) menganalisis tingkat persepsi terhadap inovasi dan partisipasi petani dalam replanting kelapa sawit; (2) menganalisis hubungan karakteristik internal dan eksternal perani dengan persepsi dalam replanting kelapa sawit dan (3) menganalisis hubungan persepsi dengan partisipasi petani dalam replanting kelapa sawit.

\section{Metode Penelitian}

Peubah independent di penelitian ini adalah karakteristik internal dan eksternal para petani yang melakukan replanting. Faktor internal petani meliputi umur, pendidikan formal, jumlah anggota keluarga,serta luas lahan dan motivasi. Faktor eksternal dari petani meliputi tingkat ketersediaan sarana produksi, frekuensi mengikuti kegiatan penyuluhan, tingkat akses informasi, frekuensi penyuluhan dan dampak perkebunan besar yang dirasakan petani, sedangkan peubah dependent penelitianiniadalah persepsi dan partisipasiyangmeliputi tingkat keuntungan relatif, tingkat kompatibilitas, tingkat kompleksitas, tingkat triabilitas, tingkat observabilitas, tingkat penerapan teknologi budidaya kelapa sawit, pecatatan daan pengaturan keuangan. Penelitian ini dilakukan di Desa Marga Mulya dan Desa Mekar Sari, Kecamatan Sungai Bahar, Kabupaten Muaro Jambi mulai bulan Maret sampai Mei 2015. Penelitian ini menggunakan pendekatan survei dengan unit analisis yaitu individu. Responden dalam penelitian ini adalah petani, ketua kelompok tani dan informan kunci (perusahaan PTPN VI, Dinas Perkebunan Provinsi Jambi, penyuluh, tokoh masyarakat dan pemerintah setempat).

Metode yang digunakan untuk menentukan jumlah sampel adalah menggunakan rumus 
Tabel 1 Jumlah sebaran data populasi dan sampel penelitian

\begin{tabular}{cccc}
\hline No & Nama Desa & $\begin{array}{c}\text { Jumlah populasi } \\
\text { (orang) }\end{array}$ & $\begin{array}{c}\text { Jumlah sampel } \\
\text { (orang) }\end{array}$ \\
\hline 1 & Suka Makmur & 200 & 33 \\
2 & Marga Mulya & 300 & 50 \\
\hline Jumlah & & 500 & 83 \\
\hline
\end{tabular}

Slovin (Sevilla et al., 2007). Jumlah sampel dalam penelitian ini yaitu 83 responden dan merupakan petani yang telah melaksanakan peremajaan kelapa sawit dan merupakan para petani eks Transmigran (Tabel 1). Penentuan jumlah sampel pada masingmasing desa ditentukan secara proportional simple rendom sampling yang mengacu pada pada rumus (Nasir, 1988). Teknik analisis data yang digunakan pada penelitian ini adalah teknik analisis statistik deskriptif dan korelasional. Analisis statistik deskriptif dilakukan untuk menganalisis persepsi terhadap inovasi replanting, tingkat partisipasi dan uji korelasi rank Spearman digunakan untuk menganalisis hubungan antara peubah independent dengan dependent.

Hasil analisis uji instrumentasi menggunakan bantuan program SPSS versi 20 dan didapat bahwa seluruh butir pernyataan dalam instrumen penelitian tergolong valid. Hasil uji coba instrumen juga menunjukkan bahwa nilai koefisien reliabilitas Alpha Cronbach pada seluruh variabel (karakteristik internal, karakteristik eksternal, persepsi terhadap inovasi replanting dan partisipasi) termasuk kategori reliabel dengan kisaran nilai reliabilitas Alpha Cronbach yaitu 0,661 sampai dengan 0,853 .

\section{Hasil dan Pembahasan}

\section{Karakteristik Petani yang Melakukan Replanting}

Karakteristik petani dalam penelitian ini terdiri dari faktor internal dan faktor eksternal. Faktor internal meliputi (umur, tingkat pendidikan, jumlah anggota keluarga, luas lahan dan juga motivasi berusahatani), sedangkan faktor-faktor eksternal meliputi (tingkat ketersediaan dari sarana produksi, frekuensi mengikuti kegiatan penyuluhan, tingkat akses informasi dan juga dampak perkebunan besar yang dirasakan petani). Karakteristik petani pada dasarnya merupakan sifat yang dimiliki oleh seseorang petani biasanya diperlihatkan melalui sikap, cara berfikir dan juga cara bertindak dan berinteraksi dalam lingkungannya. Karakterstik petani bersifat individual yaitu berbeda dari satu orang ke orang yang lain. Menurut Siagian (2008) karakteristik individu dapat diartikan sebagai kondsi individu yang dapat dilihat dari umur, jenis kelamin, status perkawinan, dan jumlah tanggungan serta masa kerja. Hasil penelitian Manoppo et al., (2009) dan Malta et al., (2008) menyebutkan bahwa faktor -faktor internal yang memengaruhi partisipasi antara lain adalah motivasi, sifat kosmopolitan, peran produktif, pendidikan formal, interaksi dengan penyuluh, sarana produksi, dan keterlibatan dalam kelompok tani.

\section{Karakteristik Internal Petani}

Karakteristik internal petani pada penelitian ini meliputi (1) umur, (2) tingkat pendidikan, (3) jumlah tanggungan keluarga, (4) luas lahan dan (5) motivasi, deskripsi dari masing-masing faktor internal dijelaskan lebih lanjut pada Tabel 2. Sebagian besar petani berada pada usia yang tergolong produktif dan hanya terdapat sebagian kecil dari petani yang sudah tua. Dari segi kesehatan dan kemampuan bekerja petani dengan usia produktif mempunyai kemampuan bekerja dan beraktifitas yang lebih tinggi dibandingkan dengan yang sudah tidak produktif. Hasil penelitian Malta (2008) menyebutkan bahwa dalam proses adopsi inovasi petani yang berada pada usia produktif lebih cepat tanggap dibandingkan dengan yang berumur tua, karena telah terjadi penurunan kondisi fisik, lambat dalam proses pengambilan keputusan serta penuh pertimbangan dan kehati-hatian. Sebagian besar petani $(65,06 \%)$ yang melakukan replanting berusia di atas 45 sampai 59 tahun.

Pada umumnya para petani memiliki tingkat pendidikan yang rendah, lebih dari sepertiga persen 
Tabel 2 Distribusi sampel berdasarkan karakteristik internal petani

\begin{tabular}{llcccc}
\hline No & Sub Variabel & Nilai skor & Kategori & $\begin{array}{c}\text { Jumlah } \\
\text { (orang) }\end{array}$ & $\begin{array}{c}\text { Persentase } \\
\text { (\%) }\end{array}$ \\
\hline 1 & Umur & $29-44$ & Dewasa muda & 11 & 13,25 \\
& & $45-59$ & Dewasa tengah & 54 & 65,06 \\
& & $60-75$ & Tua & 18 & 21,69 \\
2 & \multirow{2}{*}{ Tingkat pendidikan } & $0-6$ & Rendah & 32 & 38,55 \\
& & $7-9$ & Sedang & 22 & 26,51 \\
& & $10-12$ & Tinggi & 29 & 34,94 \\
3 & \multirow{2}{*}{ Jumlah tanggungan } & $0-2$ & Kecil & 58 & 69,88 \\
& keluarga & $3-4$ & Sedang & 20 & 24,10 \\
& & $4-6$ & Besar & 5 & 6,02 \\
4 & Luas lahan & $2-4,6$ & Kecil & 66 & 79,52 \\
& & $4,7-7,2$ & Sedang & 5 & 6,02 \\
& & $7,3-60$ & Besar & 12 & 14,46 \\
5 & Motivasi & $8-11$ & Rendah & 8 & 9,64 \\
& & $11,1-15$ & Sedang & 46 & 55,42 \\
& & $15,1-19$ & Tinggi & 29 & 34,94 \\
\hline
\end{tabular}

petani hanya menyelesaikan pendidikan formalnya di bangku sekolah dasar dan ada juga yang tidak pernah mengenyam pendidikan di sekolah formal, namun sebagian besar petani bisa menulis dan membaca serta berbahasa Indonesia. Lebih dari $50 \%$ petani dengan kategori pendidikan sedang dan tinggi. Hasil penelitian Manoppo (2009) menyatakan bahwa tingkat pendidikan juga menentukan kemampuan seseorang dalam mencerna informasi yang telah diberikan dan berhubungan dengan kualitas kerja dalam melakukan usahatani, wanita tani yang berpendidikan tinggi lebih bisa membudidayakan kakao ke arah agribisnis, bukan sekedar pemenuhan kebutuhan keluarga saja.

Sebagian besar petani $(69,88 \%)$ memiliki jumlah tanggungan keluarga dalam kategori kecil yaitu memiliki 2 orang atau kecil dari 2 orang. Sebagian besar petani mengikuti program Keluarga Berencana (KB). Hanya sebagian kecil petani $(34,94 \%)$ yang memiliki anggota keluarga dalam kategori banyak (lebih dari 4 orang) dan hal ini menandakan bahwa sebagian besar petani tidak terbebani oleh jumlah tanggungan keluarganya.

Luas lahan yang dimiliki petani bervariasi, namun sebagian besar $(79,52 \%)$ memiliki lahan sesuai jatah yang diberikan pemerintah yaitu $2 \mathrm{Ha}$ untuk kebun, 0,25 Ha untuk pekarangan dan 0,75 Ha untuk lahan tanaman pangan dengan total $3 \mathrm{Ha}$. Petani juga telah menggarap semua lahan yang dimilikinya menjadi kebun kelapa sawit dengan hanya menyisakan areal pekarangan halaman rumah dan sedikit pekarangan belakang rumah, ada juga petani yang menjual lahan pekarangan dan bahkan membeli lahan lahan petani lain untuk ditanami kelapa sawit sehingga luas lahan yang dimilikinya menjadi bertambah.

Pada umumnya motivasi yang dimiliki petani dalam melaksanakan replanting pada kategori sedang dan tinggi. Sebagian besar petani memiliki motivasi yang kuat untuk melakukan replanting karena petani menyadari pentingnya melakukan replanting agar tidak kehilangan mata pencahariannya. Motivasi lain petani adalah adanya bantuan dana (hibah) dempot percontohan dari pemerintah. Petani lain yang telah melihat demplot percontohan dan juga melihat secara langsung proses pelanksanaan dan hasil yang diperoleh membuat petani mau ikut melaksanakan replanting, walaupun dengan teknik yang berbeda dengan yang dianjurkan oleh pemerintah. Kekhawatiran petani akan kehilangan mata pencahariannya merupakan hambatan petani dalam melakukan replanting sehingga petani masih enggan melakukan replanting tersebut, petani juga masih berharap kepada pemerintah untuk memberikan 
Tabel 3 Distribusi sampel berdasarkan karakteristik eksternal petani

\begin{tabular}{|c|c|c|c|c|c|}
\hline No & Sub Variabel & Nilai skor & Kategori & $\begin{array}{l}\text { Jumlah } \\
\text { (orang) }\end{array}$ & $\begin{array}{c}\text { Persentase } \\
\text { (\%) }\end{array}$ \\
\hline \multirow[t]{3}{*}{1} & \multirow{3}{*}{$\begin{array}{l}\text { Tingkat ketersediaan sarana } \\
\text { produksi }\end{array}$} & $5-8$ & Rendah & 39 & 46,99 \\
\hline & & $9-11$ & Sedang & 35 & 42,17 \\
\hline & & $11-14$ & Tinggi & 9 & 10,84 \\
\hline \multirow[t]{3}{*}{2} & \multirow{3}{*}{$\begin{array}{l}\text { Frekuensi mengikuti } \\
\text { kegiatan penyuluhan }\end{array}$} & $4-6$ & Rendah & 11 & 13,25 \\
\hline & & $7-9$ & Sedang & 63 & 75,90 \\
\hline & & $10-12$ & Tinggi & 9 & 10,84 \\
\hline \multirow[t]{3}{*}{3} & \multirow[t]{3}{*}{ Tingkat akses informasi } & $4-5$ & Rendah & 19 & 22,89 \\
\hline & & $6-7$ & Sedang & 60 & 72,29 \\
\hline & & $7,1-8$ & Tinggi & 4 & 4,82 \\
\hline \multirow[t]{3}{*}{4} & \multirow{3}{*}{$\begin{array}{l}\text { Dampak perkebunan besar } \\
\text { yang dirasakan petani yang } \\
\text { dirasakan petani }\end{array}$} & $4-5$ & Rendah & 39 & 46,99 \\
\hline & & $5,1-6$ & Sedang & 31 & 37,35 \\
\hline & & $6,1-7$ & Tinggi & 13 & 15,66 \\
\hline
\end{tabular}

bantuan dana replanting kebun sawitnya.

\section{Karakteristik Eksternal Anggota Kelompok}

Ketersediaan jenis sarana produksi merupakan penunjang dalam pelaksanaan replanting kelapa sawit (Tabel 3). Sarana produksi yang dibutuhkan dalam proses replanting antara lain meliputi bibit kelapa sawit yang bersertifikat, pupuk, serta obat-obatan seperti obat pengendalian hama \& penyakit dan lain sebagainya. Terdapat $46,99 \%$ petani menyatakan bahwa sarana produksi tidak mudah didapatkan terutama bibit kelapa sawit yang bersertifikat. Terdapat $10,84 \%$ petani yang menyatakan tingkat sarana produksi cukup tersedia dan mudah didapatkan, namun harga relatif tinggi. Kesulitan mendapatkan bibit, pupuk dan obat-obatan yang bersubsidi sangat dirasakan dan meresahkan para petani. Sumarno (1989) mengemukakan bahwa perilaku petani dalam menetapkan ide baru dipengaruhi oleh ketersediaan sarana produksi. Berbagai kendala yang dihadapi oleh petani membuat petani kesulitan mengelola usahataninya. Bibit yang berkualiatas baik dan bersertifikat akan memberikan hasil yang baik pula. Bibit yang diperoleh dari penangkar di luar PTPN dan Dinas Perkebunan Provinsi Jambi, belum tentu bersertifikat dan merupakan bibit yang baik untuk dikembangkan. Petani membeli pupuk sesuai dengan kemampuannya walaupun tidak memenuhi kebutuhan pupuk dalam satu tahap pemupukan.

Frekuensi mengikuti kegiatan penyuluhan dalam kategori sedang. Lebih dari 50\% petani menilai kegiatan penyuluhan sudah banyak membantu dalam pelaksanaan replanting kelapa sawit. Diawal kegiatan penyuluhan disampaikan oleh pihak UPTD (Unit Pelaksanaan Teknis Desa) dan juga Dinas Perkebunan Provinsi Jambi, namun saat ini sudah sangat jarang dilakukan penyuluhan tentang replanting. Para petani yang membutuhkan informasi tentang replanting bisa memperolehnya dari petani yang peserta demplot percontohan dan teman sesama petani yang dianggap berhasil. Menurut Samsudin (1982) tujuan penyuluhan pertanian agar dapat menumbuhkan perubahan yang lebih terarah dalam melaksanakan usahatani.

Tingkat akses informasi para petani terhadap kegiatan replanting pada kelapa sawit dalam kategori sedang, meskipun kebanyakan petani tidak mengikuti penyuluhan namun petani mendapatkan informasi tentang replanting dari rekan sesama petani. Hasil penelitian dari Novikarumsari et al., (2014) menyebutkan bahwa peran early adopter sangatlah penting dalam menyampaikan informasi, early adopter merupakan ketua kelompok ternak yang berpengaruh sehingga mempercepat proses difusi biogas di kalangan peternak. Early adopter dalam penelitian ini merupakan anggota dari peserta demplot percontohan dan ketua kelompok tani yang dapat memberikan informasi tentang inovasi replanting kepada petani lainnya. Sejalan dengan hasil penelitian Hendrawati et al., (2014), pertukaran informasi antar petani ternyata menjadi faktor yang penting dalam penerapan inovasi di bidang pertanian. Inovasi dapat didifusikan kepada 
Tabel 4 Distribusi sampel berdasarkan persepsi terhadap inovasi replanting kelapa sawit

\begin{tabular}{cccccc}
\hline No & Sub Variabel & Nilai Skor & Kategori & $\begin{array}{c}\text { Jumlah } \\
\text { (orang) }\end{array}$ & $\begin{array}{c}\text { Persentase } \\
(\mathbf{\%})\end{array}$ \\
\hline 1 & Tingkat keuntungan relatif & $6-8,6$ & Rendah & 10 & 12,05 \\
& & $8,7-11,2$ & Sedang & 41 & 49,40 \\
& \multirow{2}{*}{2} & $11,3-14$ & Tinggi & 32 & 35,55 \\
& \multirow{2}{*}{ Tingkat kompatibilitas } & $3-5$ & Rendah & 48 & 57,83 \\
& & $5,1-7$ & Sedang & 28 & 33,73 \\
\multirow{2}{*}{3} & \multirow{2}{*}{ Tingkat kompleksitas } & $7,1-9$ & Tinggi & 7 & 8,43 \\
& & $6-8,3$ & Rendah & 54 & 65,06 \\
& & $8,4-10,6$ & Sedang & 23 & 27,71 \\
4 & \multirow{2}{*}{ Tingkat triabilitas } & $10,7-13$ & Tinggi & 6 & 7,23 \\
& & $3-5$ & Rendah & 51 & 61,45 \\
& & $5,1-7$ & Sedang & 29 & 34,94 \\
\multirow{2}{*}{5} & Tingkat observabilitas & $7,1-9$ & Tinggi & 3 & 3,61 \\
& & $3-7,3$ & Rendah & 13 & 15,66 \\
& & $7,4-9,6$ & Sedang & 37 & 44,58 \\
& & $9,3-12$ & Tinggi & 33 & 39,76 \\
\hline
\end{tabular}

petani lain melalui rekan sesama petani dengan peran serta early adopterinformasi tentang inovasi replanting yang didapatkan petani dari rekan sesama petani sejauh ini sangat membantu berlangsungnya kegiatan replanting.

Keberadaan perkebunan besar di sekitar lokasi penelitian tidak memberikan dampak yang singnifikan dalam memotivasi para petani melaksanakan kegiatan replanting. Kurang dari 50\% petani menyatakan bahwa perkebunan besar tidak memberikan sesuatu yang dapat membuatpetaniberminatuntukmelaksanakan replanting. Perkebunan besar PTPN VI yang ada di sekitar wilayah perkebuan rakyat dan dulunya menjadi mitra perkebunan rakyat melalui program revitalisasi perkebunan dengan pola PIR-Trans seharusnya memberikan informasi terkait replanting dan pengelolaanya kepada petani. Menurut Malangyudo (2012) pola PIR merupakan pola sistem kerjasama yang harusnya saling menguntungkan, utuh dan berkesinambungan. Idealnya bagi perusahaan yang dahulunya menjadi kebun inti dan perebunan rakyat menjadi kebun plasma bertanggung jawab untuk membimbing dan juga memberikan solusi dalam upaya perkembangan perkebunan rakyat. Solihin (2008) menyatakan bahwa salah satu tanggung jawab yang harus dilaksanakan oleh perusahaan adalah tanggung jawab sosial perusahaan (CSR). Fakta di lapangan bahwa perusahaan tidak memberikan bantuan dana pembinaan khususnya untuk mempercepat pelaksanaan replanting atau program-program pembinaan masyarakat lainnya.

\section{Persepsi Petani terhadap Inovasi Replanting Kelapa Sawit}

Tingkat keuntungan relatif memengaruhi petani dalam mengadosi suatu inovasi. Sebagian besar petani menyatakanbahwakeuntunganrelatifsepertikeunggulan inovasi replanting dengan sistem konvensional tumpang sari yang disarankan oleh pemerintah dilihat dari segi ekonomi, sosial, kenyamanan dan kepuasan dalam kategori baik dan sangat baik (Tabel 4). Pada saat ini petani yang memilih menggunakan sistem sisip yaitu penanaman kembali kelapa sawit dengan cara tidak menebang tanaman tua dan menanam tanaman muda di samping tanaman tua, sehingga tanaman tua masih bisa diambil hasilnya. masih dapat memanen kelapa sawitnya dan tetap melaksanakan replanting. Menjelang tanaman sisipan tersebut besar petani tetap mendapatkan peghasilan walaupun tidak berdampak baik bagi pertumbuhan kelapa sawit yang baru ditanam (disisip).

Pada tingkat kompatibilitas lebih dari setengah $(57,83 \%)$ dari jumlah responden berpendapat bahwa sistem replanting yang disarankan pemerintah belum sesuai dengan keadaan petani saat ini. Petani tidak 
Tabel 5 Distribusi sampel berdasarkan partisipasi petani dalam kegiatan replanting kelapa sawit

\begin{tabular}{clcccc}
\hline No & Sub Variabel & Nilai skor & Kategori & $\begin{array}{c}\text { Jumlah } \\
\text { (orang) }\end{array}$ & $\begin{array}{c}\text { Persentase } \\
(\%)\end{array}$ \\
\hline 1 & Tingkat penerapan teknologi & $3-5$ & Rendah & 25 & 30,12 \\
& budidaya kelapa sawit & $5,1-7$ & Sedang & 33 & 39,76 \\
& & $7,1-9$ & Tinggi & 25 & 30,12 \\
2 & \multirow{2}{*}{$\begin{array}{l}\text { Pencatatan dan pengaturan } \\
\text { keuangan }\end{array}$} & $3-5$ & Rendah & 58 & 69,88 \\
& & $5,1-7$ & Sedang & 21 & 25,30 \\
\end{tabular}

memiliki tabungan dan mata pencaharian lain untuk mempertahanan kehidupan mereka. Rogers (2003) menjelaskan bahwa pengguna inovasi (adopter) akan mempertimbangkan manfaat dari inovasi berdasarkan pengalaman dan kebutuhannya. Jika petani menganggap inovasi tersebut benar-benar dibutuhkan dan sesuai dengan kondisi yang dihadapinya maka akan semakin mudah sebuah inovasi tersebut diadopsi oleh petani. Tingkat kompleksitas merupakan tingkat dimana suatu inovasi dianggap relatif sulit atau mudah untuk diterapkan. Sebagianbesarpetani $(65,06 \%)$ menyatakan bahwa replanting dengan sistem konvensional tumpang sari sulit dilaksanakan dan dianggap merepotkan dan membutuhkan biaya yang besar, walaupun petani menyadari bahwa sistem replanting tersebut mudah untuk dipahami dan diterapkan. Kurang dari separuh $(27,71 \%)$ petani memiliki asumsi bahwa inovasi replanting yang dianjurkan pemerintah mudah untuk diterapkan apabila petani memiliki modal dan siap kehilangan mata pencahariannya sementara waktu, menjelang sawit yang ditanam bisa menghasilkan.

Tingkat triabilitas merupakan tingkat dimana suatu inovasi dapat dicoba dengan mudah. Lebih dari 50\% menyatakan bahwa inovasi replantingyang dianjurkan oleh pemerintah tidak bisa diujicobakan dalam skala kecil walaupun mudah diterapkan. Tanaman perkebunan kelapa sawit merupakan jenis tanaman perkebunan yang tidak efektif untuk dikembangkan apabila dengan luas lahan yang kurang dari 2 Ha. Sebagian kecil petani (3,61\%) menyatakan bahwa inovasi replanting bisa diujicobakan dan mayoritas petani yang berasumsi demikian adalah petani yang memiliki kebun lebih dari 2 Ha yang juga akan melakukan replanting selanjutnya pada kebunkebun lain yang dimilikinya.

Tingkat observabilitas merupakan suatu tingkat dimana suatu inovasi dapat dilihat hasilnya dan dapat dilihat prosesnya. Kurang dari 50\% petani menyatakan bahwa dapat secara langsung melihat proses peremajaan yang dianjurkan pemerintah tersebut berlangsung mulai dari pemanenan, perawatan hingga saat ini sudah fase pemanenan. Petani memperoleh informasi dari petani lain yang melaksanakan demplot percontohan baik berupa dosis pupuk atau berbagai serangan hama dan penyakit. Rogers (2003) menyatakan bahwa semakin mudah seseorang mengamati atau melihat keberhasilan sebuah inovasi maka semakin besar kemungkinan orang tersebut mengadopsi inovasi.

\section{Partisipasi Petani dalam Kegiatan Replanting Kelapa Sawit}

Partisipasi petani dalam kegiatan replanting menunjukkan tingkat keikutsertaan dan keaktifannya dalam megikuti berbagai kegiatan yang dilakukan petani dalam melaksanakan replanting. Partisipasi petani dalam replanting dalam penelitian ini (1) teknik penerapan teknologi budidaya kelapa sawit dan (2) pencatatan dan juga pengaturan keuangan, selengkapanya disajikan pada Tabel 5.

\section{Tingkat Penerapan Teknologi Budidaya Kelapa Sawit}

Tingkat penerapan teknologi budidaya kelapa sawit yang diamati dalam penelitian ini meliputi penumbangan atau pemusnahan tanaman kelapa sawit yang sudah tua, pembibitan, dan persiapan lahan. Replanting yang dilakukan oleh petani tidak serentak sehingga tidak ada patokan umur sawit yang dimiliki petani pada masing-masing petani saat penelitian dilaksanakan. Kurang dari separuh $(39,76 \%)$ petani yang menyatakan bahwa budidaya kelapa sawit dalam hal ini pelaksanaan replanting kelapa sawit mudah 
dilakukan, petani juga ada yang membudidayakan sendiri bibit yang akan ditanamnya, walaupun petani tidak mengetahui secara pasti apakah bibit tersebut bersertifikat atau tidak. Rendahnya partisipasi petani dalam penerapan teknologi budidaya kelapa sawit yang baik tentu saja karena berbagai kendala yang dihadapi oleh petani seperti rendahnya pengetahuan para petani akan pentingnya menerapkan teknologi budidaya yang baik serta rendahnya minat petani dalam mengadopsi teknologi tersebut. Hasil penelitian yang Lingani et al., (2011), di Afrika Selatan ditemukan bahwa hasil partisipasi dibentuk oleh struktur insentif bagi anggota, yang dipengaruhi oleh konteks berupa sistem jaringan sosial, sisial ekonomi, demografi serta kelembagaan internal dan eksternal. Dari penelitian tersebut terlihat bahwa terdapat banyak faktor yang mempengaruhi partisipasi dalam menerapkan suatu teknologi, bisa berasal dari diri petani maupun dari luar dirinya.

\section{Pencatatan dan Pengaturan Keuangan}

Pencatatan atau pengaturan keuangan atau dikenal dengan istilah book keeping merupakan kemampuan petani dalam mengatur pengeluaran dalam melaksanakan proses replanting. Lebih dari separuh petani $(69,88 \%)$ tidak melakukan pencatatan pada setiap pengeluaran yang dilakukan dalam rangka pelaksanaan replanting kelapa sawit. Hanya sebagian kecil petani melakukan pencatatan dan membukannya (4,82\%). Hasil penelitian Zhang (2011) menyatakan bahwa terdapat faktor-faktor yang menghambat partisipasi petani dalam konstruksi budaya masyarakat pedesaan saat ini mencakup tiga aspek yaitu (1) fasilitas budaya dasar dan kesempatan dimana petani kurang berpartisipasi dalam pembentukan budaya masyarakat pedesaan, (2) petani tidak memiliki pengetahuan yang cukup dalam konstruksi budaya masyarakat pedesaan, (3) kualitas budaya relatif rendah sehingga kemampuan petani untuk berpartisipasi menjadi rendah. Petani yang berpartisipasi melakukan pencatatan dan pengaturan keuangan dalam replanting kelapa sawit mayoritas merupakan petani yang aktif dan rajin mengikuti penyuluhan seperti petani peserta demplot percontohan, anggota aktif dalam setiap kelompok taninya maupun gapoktan. Petani peserta demplot wajib melakukan pembukuan dikarenakan akan dijadikan bukti berupa pertanggungjawaban penggunaan dana yang diberikan pemerintah selama melaksanakan replanting.

\section{Korelasi antara Faktor Internal dengan Persepsi terhadap inovasi Replanting Kelapa Sawit}

Korelasi antara faktor internal dengan partisipasi inovasi petani yaitu pada aspek jumlah keluarga dan motivasi berusahatani (Tabel 6). Jumlah tanggungan keluarga berhubungan nyata dan juga positif dengan persepsi terhadap inovasi replanting terhadap tingkat triabilitas artinya semakin tinggi jumlah tanggungan keluarga maka semakin tinggi persepsi terhadap inovasi replanting petani untuk melakukan uji coba dalam skala kecil. Apabila dikaitkan dengan pendapat Rogers (2003) bahwa sebuah inovasi bisa diujicobakan untuk mengurangi ketidakpastian dan menguji keberhasilan

Tabel 6 Korelasi antara faktor internal dengan persepsi terhadap inovasi replanting kelapa sawit di Provinsi Jambi

\begin{tabular}{|c|c|c|c|c|c|c|}
\hline \multirow[b]{2}{*}{ No } & \multirow[b]{2}{*}{ Faktor internal } & \multicolumn{5}{|c|}{ Persepsi terhadap inovasi petani replanting $\left(\mathrm{r}_{\mathrm{s}}\right)$} \\
\hline & & $\begin{array}{l}\text { Tingkat } \\
\text { keuntungan } \\
\text { relatif }\end{array}$ & $\begin{array}{c}\text { Tingkat } \\
\text { kompatibilitas }\end{array}$ & $\begin{array}{c}\text { Tingkat } \\
\text { kompleksitas }\end{array}$ & $\begin{array}{c}\text { Tingkat } \\
\text { observabilitas }\end{array}$ & $\begin{array}{l}\text { Tingkat } \\
\text { triabilitas }\end{array}$ \\
\hline 1 & Umur & $-0,190$ & 0,052 & 0,039 & 0,062 & $-0,187$ \\
\hline 2 & $\begin{array}{l}\text { Tingkat } \\
\text { pendidikan }\end{array}$ & 0,121 & $-0,137$ & 0,077 & 0,487 & 0,001 \\
\hline 3 & $\begin{array}{l}\text { Jumlah } \\
\text { tanggungan } \\
\text { keluarga }\end{array}$ & $-0,177$ & $-0,120$ & $-0,119$ & 0,007 & $0,235^{*}$ \\
\hline 4 & Luas lahan & $-0,087$ & 0,125 & 0,104 & $-0,053$ & 0,045 \\
\hline 5 & $\begin{array}{l}\text { Motivasi } \\
\text { berusahatani }\end{array}$ & $-0,107$ & $-0,218$ & $-0,333^{* *}$ & $-0,130$ & $0,410^{* *}$ \\
\hline
\end{tabular}


suatu inovasi.

Motivasi petani berhubungan sangat nyata dan negatif dengan persepsi terhadap inovasi replanting pada tingkat kompleksitas artinya para petani yang memiliki motivasi rendah lebih melihat replanting kelapa sawit yang dianjurkan oleh pemerintah mudah untuk diterapkan. Motivasi juga berhubungan sangat nyata dan positif dengan persepsi terhadap inovasi replanting pada tingkat triabilitas artinya apabila motivasi tinggi maka tingkat triabilitasnya semakin tinggi, begitu juga sebaliknya. Menurut Malta (2008) motivasi merupakan modal yang sangat penting bagi petani untuk menunjang kesuksesan dalam berusahatani di mana motivasi yang tinggi diperlukan untuk mendorong petani dalam berusahatani dan menerima atau mengadopsi informasi atau teknologi yang baru guna meningkatkan hasil usahataninya. Kegiatan sosial berupa komitmen perusahaan secara sukarela untuk turut meningkatkan kesejahteraan masyarakat, khususnya masyarakat sekitar lokasi perusahaan.

Faktor-faktor internal yang tidak berhubungan dengan persepsi inovasi replantingkelapa sawit antara lain adalah umur petani, tingkat pendidikan dan luas lahan. Umur petani berkisar antara 29-75 tahun dan didominasi oleh petani yang berumur dewasa tengah, walaupun demikian petani dari kalangan umur dewasa muda sampai tua memiliki pandangan yang positif terhadap replanting. Petani yang tergolong kategori umur tua juga ada yang masih produktif bekerja di kebun dan mengelola kebunnya secara mandiri. Pendidikan formal petani masih tergolong rendah namun, seharusnya tidak menjadi hambatan petani dalam proses belajar. Penyuluhan menurut Asngari (2001) merupakan sistem pendidikan non formal untuk mengubah perilaku sumber daya manusia (SDM)-Klien sesuai dengan yang direncanakan. Luas lahan tidak berhubungan dengan persepsi inovasi replanting. Berbeda dengan pendapat Khakheili dan Zamani (2009) bahwa luas lahan merupakan salah satu faktor yang membuat petani dapat parpartisipasi aktif dalam mengelola irigasi. Petani memiliki luas lahan yang beragam, semula petani hanya memiliki lahan $2 \mathrm{Ha}$, lahan pekarangan $0,25 \mathrm{Ha}$ dan lahan pangan $0,75 \mathrm{Ha}$.

\section{Korelasi antara Faktor Eksternal dengan Persepsi terhadap inovasi Replanting Kelapa Sawit}

Frekuensi mengikuti kegiatan penyuluhan berhubungan sangat nyata dan positif dengan persepsi terhadap inovasi replanting pada tingkat triabilitas artinya semakin sering dilakukan penyuluhan maka persepsi terhadap inovasi replanting untuk melakukan replanting dalam skala kecil akan semakin tinggi (Tabel 7). Menurut Arifah (2002) dalam Suparti (2004) bahwa salah satu faktor yang

Tabel 7 Korelasi antara faktor eksternal dengan persepsi terhadap inovasi replanting kelapa sawit di Provinsi Jambi

\begin{tabular}{|c|c|c|c|c|c|c|}
\hline \multirow[b]{2}{*}{ No } & \multirow[b]{2}{*}{ Faktor internal } & \multicolumn{5}{|c|}{ Persepsi terhadap inovasi petani replanting $\left(r_{s}\right)$} \\
\hline & & $\begin{array}{c}\text { Tingkat } \\
\text { keuntungan } \\
\text { relatif }\end{array}$ & $\begin{array}{c}\text { Tingkat } \\
\text { kompatibilitas }\end{array}$ & $\begin{array}{c}\text { Tingkat } \\
\text { kompleksitas }\end{array}$ & $\begin{array}{c}\text { Tingkat } \\
\text { observabilitas }\end{array}$ & $\begin{array}{l}\text { Tingkat } \\
\text { triabilitas }\end{array}$ \\
\hline 1 & $\begin{array}{l}\text { Tingkat ketersediaan } \\
\text { sarana produksi }\end{array}$ & $-0,055$ & $-0,067$ & $-0,088$ & 0,096 & 0,140 \\
\hline 2 & $\begin{array}{l}\text { Frekuensi mengikuti } \\
\text { kegiatan penyuluhan }\end{array}$ & $-0,155$ & $-0,118$ & $-0,381 * *$ & $-0,117$ & $0,329 * *$ \\
\hline 3 & $\begin{array}{l}\text { Tingkat akses } \\
\text { informasi }\end{array}$ & 0,004 & $-0,130$ & $-0,043$ & $-0,027$ & 0,129 \\
\hline 4 & $\begin{array}{l}\text { Dampak perkebunan } \\
\text { besar yang dirasakan } \\
\text { petani }\end{array}$ & 0,089 & $-0,146$ & $-0,055$ & 0,126 & $0,261 *$ \\
\hline
\end{tabular}

\section{Keterangan:}

*) nyata pada $\mathrm{p}<0,05$

rs : Koefisien rank Spearman

**) sangat nyata pada $\mathrm{p}<0,01$ 
memengaruhi tingkat partisipasi para petani adalah intensitas penyuluhan. Frekuensi mengikuti kegiatan penyuluhan berhubungan sangat nyata dan negatif dengan persepsi terhadap inovasi replanting pada tingkat kompleksitas artinya semakin sering dilakukan penyuluhan maka persepsi terhadap inovasi replanting pada kelapa sawit semakin mudah dilakukan oleh para petani karena petani lebih paham tentang cara replanting tersebut. Hasil penelitian Edwina dan Maharani(2010) menyimpulkan bahwa semakin rumit suatu inovasi, maka akan sulit bagi petani menerima inovasi tersebut, sebaliknya apabila inovasi mudah diterapkan, semakin mudah bagi teknologi tersebut dipraktekkan sehingga proses adopsi inovasi semakin cepat. Apabila tingkat kerumitan suatu inovasi rendah maka kemungkinkan petani untuk mencobanya lebih besar. Frekuensi mengikuti kegiatan penyuluhan dinilai belum maksimal karena belum mampu membuat petani memiliki persepsi yang baik pada tingkat keuntungan relatif, tingkat kompatibilitas dan tingkat observabilitas.

Dampak dari perkebunan besar yang dirasakan petani berhubungan nyata dan positif dengan tingkat triabilitas artinya petani yang melihat hasil replanting yang dilakukan oleh perusahaan memiliki persepsi terhadap adanya inovasi replanting yang tinggi untuk mencoba melakukan replanting dalam skala kecil. Menurut Mara dan Fitri (2011) perkebunan besar seperti perkebunan pemerintah dan swasta seharusnya memberikan dampak yang positif bagi perkembangan desa terutama pada aspek demografi, pendapatan dan berbagai aspek lainnya. Menurut Fauziah (2014) dampak dari perkebunan besar bisa berupa CSR yang tujuannya adalah pembangunan berkelanjutan dan terus menerus. Menurut hasil penelitian Salampissy et al., (2010) bahwa antara stakeholder saling berkaitan dan bersama-sama sehingga kelemahan dari peranserta stakeholder dapat saling melengkapi.

Faktor eksternal yang tidak berhubungan dengan persepsi inovasi replanting kelapa sawit antara lain adalah tingkat ketersediaan sarana produksi dan tingkat akses informasi. Tingkat ketersediaan sarana produksi dinilai masih rendah khususnya pada tersediaanya bibit yang bersertifikat dan pupuk. Menurut Siregar (2006), dalam memilih teknologi yang digunakan masyarakat sebagai pengguna inovasi teknologi harus lebih selektif karena berkaitan dengan biaya yang dikeluarkan. Pada tingkat akses informasi tidak berhubungan dengan persepsi inovasi replanting. Bertentangan dengan hasil penelitian Hendrawati et al., (2014) menyatakan bahwa pertukaran informasi antar petani ternyata menjadi faktor yang penting dalam penerapan inovasi di bidang pertanian. Akses informasi menyebabkan terjadinya penyebaran dan pertukaran informasi pada petani.

\section{Korelasi antara Persepsi terhadap inovasi Replanting dengan Partisipasi Petani dalam Melaksanakan Replanting Kelapa Sawit}

Persepsi terhadap inovasi replanting pada tingkat triabilitas berhubungan nyata dan negatif dengan tingkat penerapan teknologi budidaya kelapa sawit artinya setelah petani melihat replanting pada demplot percontohan dengan penerapan teknologi budidaya yang sesuai dengan anjuran pemerintah (sistem replanting konvensional tumpang sari dengan

Tabel 8 Korelasi antara persepsi terhadap inovasi replanting kelapa sawit dengan partisipasi petani dalam melaksanakan replanting kelapa sawit Provinsi Jambi

\begin{tabular}{clcc}
\hline No & \multicolumn{1}{c}{$\begin{array}{c}\text { Persepsi terhadap inovasi } \\
\text { replanting kelapa sawit }\end{array}$} & $\begin{array}{c}\left.\text { Partisipasi petani dalam replanting kelapa sawit (r } \mathbf{r}_{\mathbf{s}}\right) \\
\text { Tingkat penerapan teknologi } \\
\text { budidaya kelapa sawit }\end{array}$ & $\begin{array}{c}\text { Pencatatan dan } \\
\text { pengaturan keuangan }\end{array}$ \\
\hline 1 & Tingkat keuntungan relatif & $-0,071$ & $-0,039$ \\
2 & Tingkat kompatibilitas & 0,178 & $-0,111$ \\
3 & Tingkat kompleksitas & 0,151 & $-0,105$ \\
4 & Tingkat observabilitas & 0,185 & $-0,176$ \\
5 & Tingkat triabilitas & $\mathbf{- 0 , 0 4 2 *}$ & 0,139 \\
\hline
\end{tabular}

Keterangan:

*) nyata pada $\mathrm{p}<0,05$

rs: Koefisien rank Spearman

**) sangat nyata pada $\mathrm{p}<0,01$ 
menubang total kelapa sawit tua) menjadi rendah karena petani cenderung melakukan replanting dengan sistem sisip dan tidak menumbang seluruh pohon kelapa sawit yang sudah tua (Tabel 8). Hasil penelitian Edwina dan Maharani (2010) menyatakan bahwa petani cenderung untuk mengadopsi inovasi jika telah dicoba dalam skala kecil di lahannya sendiri dan terbukti lebih baik daripada mengadopsi inovasi dalam skala besar, karena inovasi menyangkut banyak resiko. Tingkat triabilitas tidak berhubungan dengan partisipasi petani dalam replanting kelapa sawit pada aspek pencatatan dan pengaturan keuangan. Persepsi terhadap inovasi replanting dalam penelitian ini justru memengaruhi petani dalam aspek budidaya dikarenakan partisipasi yang berlangsung pada tahap triabilitas justru tidak dilaksanakan oleh petani. Petani yang melakukan replanting pada salah satu kebun yang dimiliki cenderung mempekerjakan orang lain dan tidak berpartisipasi secara langsung pada aspek budidaya tersebut. Tingkat triabilitas juga tidak berhubungan dengan pencatatan dan pengaturan bidang keuangan artinya apabila tingkat triabilitas tinggi maka partisipasi petani dalam pencatatan dan pengaturan keuangan menjadi tinggi.

Persepsi terhadap inovasi replanting pada tingkat keuntungan relatif tidak berhubungan dengan partisipasi petani dalam replanting kelapa sawit pada aspek tingkat penerapan teknologi budidaya kelapa sawit dan pencatatan, pengaturan keuangan artinya persepsi terhadap inovasi replanting pada tingkat keuntungan relatif yang tinggi tidak menjamin dengan partisipasi petani pada tingkat penerapan teknologi budidaya kelapa sawit serta pencatatan dan pengaturan keuangan menjadi baik. Petani menyatakan bahwa tingkat keuntungan relatif inovasi replanting dengan sistem sisip dianggap lebih baik dan dan lebih unggul dari inovasi sebelumnya, membuat petani justru tidak melakukan teknologi budidaya yang sesuai dengan saran yang diberikan oleh pemerintah dan tidak melakukan pencatatan dan pengaturan keuangan dengan baik. Hal ini bertentangan dengan hasil penelitian Elhaq dan Satria (2011) yang menyatakan bahwa terdapat korelasi antara persepsi mengenai fungsi ekologi magrove dengan partisipasi pesanggem dan pengelolaan tambak magrove ramah lingkungan model empang pantai.

Persepsi terhadap inovasi replanting pada tingkat kompatibilitas tidak berhubungan dengan partisipasi petani dalam replanting kelapa sawit pada aspek tingkat penerapan teknologi budidaya kelapa sawit, pencatatan dan pengaturan keuangan artinya tingkat kompleksitas yang tinggi tidak menjamin akan membuat partisipasi petani dalam penerapan teknologi budidaya kelapa sawit serta pencatatan dan pengaturan keuangan saat replanting juga tinggi. Apabila petani menganggap replanting yang dilakukanya tidak menimbulkan hal buruk bagi lingkungan dan tidak melanggar norma-norma yang ada maka petani maka dalam hal ini tidak memiliki korelasi dengan partisipasi para petani. Anggapan dari masyarakat bahwa walaupun inovasi replanting dibutuhkan oleh petani namun petani tidak bisa mengadopsinya.

Persepsi terhadap inovasi replanting pada tingkat kompleksitas tidak berhubungan dengan partisipasi petani dalam replanting kelapa sawit pada aspek tingkat penerapan teknologi budidaya kelapa sawit serta pencatatan dan pengaturan keuangan artinya tingkat kompleksitas yang tinggi tidak menjadi faktor penentu tingginya partisipasi petani dalam melakukan tingkat penerapan teknologi budidaya tanaman kelapa sawit serta pencatatan dan pengaturan keuangan. Petani beranggapan bahwa sistem replanting yang dilakukannya memudahan petani, sehingga petani terus menerus melakukannya. Petani bisa dikatakan tidak terbiasa melakukan pencatatan dan pengaturan keunagan dengan baik, karena petani merasa hal itu tidak perlu, lain halnya dengan petani yang melakukan sistem peremajaan dan merupakan peserta dari demplot percontohan, dimana petani tersebut membuat dan merinci pegeluarannya dalam melakukan replanting untuk dilaporkan kepada pemerintah sebagai pemberi dana.

Persepsi terhadap inovasi replanting pada tingkat observabilitas tidak berhubungan dengan partisipasi petani dalam replanting kelapa sawit pada aspek tingkat penerapan teknologi budidaya kelapa sawit serta pencatatan dan pengaturan keuangan artinya tingkat observabilitas yang baik tidak menjamin inovasi replanting pada penerapan teknologi budidaya kelapa sawit, pencatatatan dan pengaturan keuangan menjadi tinggi. Di lokasi penelitian petani yang telah menerapkan replanting sacara konvensional tidak langsung menggarap lahannya sebagai areal tumpang sari, melainkan memberikan kesempatan bagi petani lain yang mau mengelola kegiatan tumpang sari di lokasi replanting 
sacara gratis. Petani yang melakukan replanting secara konvensional justru menginginkan petani lain yang menggarap kebunnya dengan pola tumpang sari. Petani justru merasa terbantu karena pihak yang melakukan tumpang sari akan membersihkan kebunnya dan memberikan pupuk pada tanaman tumpang sari. Petani berasumsi bahwa pupuk yang digunakan untuk tanaman tumpang sari juga bisa diserap oleh tanaman kelapa sawit yang baru direplanting.

Hasil penelitian dari Kholiq et al., (2008) menunjukkan bahwa parsepsi masyarakat berhubungan positifdengan tingkat partisipasi. Sementara itu Asngari (1984) berpendapat bahwa persepsi setiap individu terhadap lingkungannya merupakan salah satu faktor penting karena akan berpengaruh pada penentuan tindakan yang akan diambilnya. Hasil penelitian Puspasari (2010) tingkat persepsi masyarakat terhadap pengembangan tanaman karet unggul disebabkan oleh faktor dari luar diri petani yang mendorong timbulnya pertisipasi, yaitu adanya bantuan dan insentif yang diberikan pihak pemerintah. Tidak sedikit petani yang memilih melakukan replanting karena adanya bantuan dari pemerintah seperti pada demplot percontohan. Suparti (2004) mengemukakan bahwa orang yang berpersepsi baik belum tentu bisa berpartisipasi dengan baik pula, hal ini disebabkan oleh ketidakmampuannya dan kondisi lingkungan yang tidak mendukung orang untuk berpartisipasi. Kemauan berasal dari motivasi yang dimiliki oleh seseorang baik berasal dari luar dirinya maupun dari dalam dirinya yang diperoleh dari pengalaman hidup dan pengetahuan yang dibangunnya tentang suatu objek. Uraian di atas menjelaskan bahwa keterkaitan antara persepsi dan partisipasi sangatlah erat. Apabila ingin mengharapkan petani untuk barpartisipasi maka terlebih dahulu diberikan penyuluhan berupa pengetahuan agar membentuk persepsi yang positif sehingga petani mampu berpartisipasi dengan baik.

Implikasi dari hasil penelitian ini adalah perlu adanya hal-hal yang ditingkatkan, ketersediaan sarana produksi khususnya bibit kelapa sawit yang bersertifikat, sehingga petani bisa mempertahankan kualiatas kelapa sawitnya. Frekuensi mengikuti kegiatan penyuluhan diharapkan dapat dilakukan secara rutin dan petani informasi dan pengetahuan agar petani mau melaksankan sistem replantingyang sesuai dengan anjuran pemerintah. Akses informasi dapat petani peroleh dari penyuluh, rekan sesama petani khususnya petani yang melakukan demplot percontohan. Keberadaan perkebunan besar harusnya mampu memberikan informasi bagi para petani dan memberikan pasokan bibit yang dibutuhkan petani.

\section{Kesimpulan}

Persepsi petani terhadap inovasi replantingdinilai cukup menguntungkan dan cukup mudah diamati hasil penerapannnya, namun cukup rumit untuk diterapkan sesuai dengan anjuran pemerintah karena tidak sesuai dengan kebutuhan petani dan tidak dapat dicoba dalam skala kecil. Partisipasi petani dalam kegiatan replanting pada aspek teknik budidaya tergolong sedang yaitu petani aktif melakukan perawatan namun hanya sebagian kecil yang mengunakan bibit bersertifikat dan melakukan penumbangan tidak sesuai dengan anjuran pemerintah dan petani tidak melakukan pencatatan dan pengaturan keuangan dengan baik.

Faktor internal yang penting diperhatikan untuk mengembangkan pengetahuan petani sehingga memiliki persepsi inovasi yang positif terhadap replanting kelapa sawit adalah pendidikan formal. Faktor ekternal yang penting diperhatikan agar petani dapat mengembangkan pengetahuan petani sehingga memiliki persepsi inovasi yang positif terhadap replanting kelapa sawit adalah: tingkat ketersediaan dari sarana produksi khususnya menggunaan bibit unggul yang bersertifikat, frekuensi mengikuti kegiatan penyuluhan.

Partisipasi petani dalam kegiatan replanting kelapa sawit masih rendah karena petani hanya sedikit yang melakukan dan menerapkan sistem peremajaan yang dianjurkan oleh pemerintah dengan teknologi budidaya yang sesuai dengan demplot percontohan. Para petani juga tidak melakukan pencatatan dan juga pengaturan keuangan dengan baik karena petani tidak terbiasa melakukannya dan tidak menganggap penting hal tersebut. Tidak terdapat hubungan antara persepsi terhadap inovasi replanting dengan partisipasi petani dalam replantingkecuali pada aspek tingkat triabilitas.

\section{Daftar Pustaka}

Asngari PS. 2001. Peranan Agen Pembaruan/ Penyuluh dalam Usaha Memberdayakan (Empowerment) Sumber Daya Manusia Pengelola Agribisnis, Orasi Ilmiah Guru Besar Tetap Ilmu Sosial Ekonomi, Fakultas Peternakan. Bogor (ID): Institut Pertanian Bogor. 
1984. Persepsi Direktur Penyuluhan Tingkat Keresidenan dan Kepala Penyuluhan Pertanian terhadap Peranan dan Fungsi Lembaga Penyuluhan Pertanian di Negara Bagian Texas Amerika Serikat. Jurnal Media Peternakan 9 (2).

Direktorat Jenderal Perkebunan. 2013. Peningkatan Produksi, Produktivitas dan Mutu Tanaman Tahunan Pedoman Teknis Revitalisasi Perkebunan. Jakarta (ID): Kementerian Pertanian.

Edwina S. Maharani T. 2010. Persepsi Petani terhadap Inovasi Teknologi Pengolahan Pakan Ternak di Kecamatan Kerinci Kanan Kabupaten Siak. Indonesian Journal of Agriculture Economis $2: 170-183$.

Elhaq IH, Satria A. 2011. Persepsi Pesanggem mengenai Hutan Mangrove dan Partisipasi Pesanggem dalam Pengelolaan Tambak Mangrove Ramah Lingkungan Model Empang Parit. Jurnal Transdisiplin Sosiologi, Komunikasi, dan Ekologi Manusia/Sodality 5: 97-103.

Fauziah. 2014. Pelaksanaan Program Community Development dalam Aktivitas Corporate Social Responsibility PT. Mahakam Sumber Jaya Coal Mining (Studi di Desa Kerta Buana Kec. Tenggarong Seberang Kab.Kukar). eJournal Ilmu Komunikasi 2: 287-301

Hendrawati E, Yunsnthae E, Radian. 2014. Analisis Persepsi Petani dalam Penggunaan Benih Unggul Padi di Kecamatan Muara Pawan Kabupaten Ketapang. Jurnal Social Economic of Agriculture 3 : 53-57.

Herawati, Pulungan I. 2006. Faktor-faktor yang Berhubungan dengan Partisipasi Kontak tani dalam Perencanaan Program Penyuluhan Pertanian (Kasus WKUPP Nyalindung, Kabupaten Sukabumi). Jurnal Penyuluhan Institut Pertanian Bogor: 2 (2).

Khakheili TA, Zamani GH. 2009. Farmer Participation in Irrigation Management: The Case of Doroudzen Dam Irrigation Network, Iran. Jurnal Aagricultural Water Management 3 : 859-865.

Kholiq, Hardiansyah, Djamaludin MD. 2008. Persepsi dan Partisipasi dalam Pengembangan Lumbung Pangan di Kabupaten Lampung Barat. Jurnal Gizi dan Pangan Institut Pertanian Bogor $3: 217-226$.
Lingani PC, Savadogo PS, Tigabu M, Oden PC. 2011. Factors Influencing People's Participation in The Forest Management Program in Burkina Faso, West Africa. Journal of Forest Policy and Economics 13 : 292-302.

Malangyudo A. 2012. Kiat Sukses Berkebun Kelapa Sawit, agar Produktivitas Kelapa Sawit Meningkat. Jakarta (ID). Media Perkebunan.

Muljono P. 2012. Metode Penelitian Sosial. Bogor (ID): IPB Press.

Malta. 2008. Kompetensi Petani Jagung dalam Berusahatani di Lahan Gambut: Kasus Petani Jagung di Lahan Gambut di Desa Limbung Kabupaten Pontianak Kalimantan Barat. [tesis]. Bogor (ID): Institut Pertanian Bogor.

Manoppo CN. 2009. Faktor-Faktor yang Berhubungan dengan Partisipasi Wanita tani dalam Usahatani Kakao (kasus di Kecamatan Palolo Kabupaten Donggala Provinsi Sulawesi Tengah). [tesis]. Bogor (ID): Institut Pertanian Bogor.

Mara A, Fitri Y. 2011. Dampak Perkebunan Besar yang Dirasakan Petani Kelapa Sawit terhadap Perekonomian Desa di Provinsi Jambi. [laporan Penelitian]. Jambi (ID): Universitas Jambi.

Nasir M. 1988. Metode Penelitian. Jakarta (ID): Ghalia Indonesia.

Neupane RP, Sharma KR, Thap GB. 2002. Asoption of Agroforestry in the Hills of Nepal, A Logistic Regression Analysis. Journal of Agriculture Systems $7: 177-196$

Novikarumsari ND, Amanah S, Ginting BS. 2014. Tingkat Difusi-Adopsi Inovasi Biogas oleh Peternak Sapi Perah di Kecamatan Lembang Kabupaten Bandung Barat. Jurnal Penyuluhan 10 (2).

Puspasari S. 2010. Persepsi dan Partisipasi Peladang Berpindah dalam Kegiatan Pengembangan Tanaman Kehidupan Model HTI Terpadu di Kalimantan Barat. [tesis]. Bogor (ID): Institut Pertanian Bogor.

Rogers E. 2003. Diffusion of Innovations Fifth Edition. New York (AS): The Free Pr.

Salampessy ML, Nugroho B, Purnomo H. 2010.

Persepsi Kelompok Masyarakat dalam Pengelolaan Kawasan Hutan Lindung Khusus di Hutan Lindung Gunung Nova Kota Ambon Provinsi Maluku. Jurnal perennial 6 : 99-107. Samsudin U. 1982. Dasar-Dasar Penyuluhan dan 
Modernisasi Pertanian. Bandung (ID): Bina cipta.

Sevilla CG, JA Ochave, TG Punsalan, BP Regala, GG Uriate. 2007. Research Methods. Quezon City (PH): Rex Printing Company.

Siagian SP. 2008. Manajemen Sumber Daya Manusia. Jakarta (ID): Bumi Aksara

Siregar C. 2006. Analisis sosiologi terhadap inovasi teknologi. Jurnal Sosio Teknolog 9 (5).

Solihin I. 2008. Coporate Sosial Responsibility From Charity to Sustainability. Jakarta (ID). Salemba Empat.

Sumarno. 1989. Bimbingan dan Penyuluhan Pendidikan. Jakarta (ID): Gramedia.

Suparti E. 2004. Tingkat partisipasi masyarakat pengolah dalam pengelolaan lingkungan sentra pengolahan hasil perikanan (kasus di PHPT Muara Angke). [tesis]. Bogor (ID): Institut Pertanian Bogor.

Zhang X, Lu Y. 2011. Reflection on Farmers Participation in Rural Community Cultural Construction. Journal Asian Social Science 7 : 240-243. 